\title{
Phytochemical Analysis, Mineral Composition and in vitro Antioxidant Activities of Chromolaena odorata Leaves
}

\author{
Usunobun Usunomena $^{1 *}$, Ewere Godwin Efosa ${ }^{2}$ \\ ${ }^{1 *}$ Department of Basic Sciences (Biochemistry unit), Faculty of Basic and Applied sciences, \\ Benson Idahosa University, Benin City, Edo State, Nigeria, uusunobun@biu.edu.ng \\ ${ }^{2}$ Department of Biochemistry, Faculty of Basic Medical Sciences, University of Uyo, \\ Akwa Ibom State, Nigeria \\ "Corresponding author: uusunobun@biu.edu.ng
}

\begin{abstract}
Objective: Chromolaena odorata is used in traditional medicine in Nigeria to remedy malaria, abdominal and cervical pain and as local antiseptic agent for wound. This study was carried out to identify bioactive agents and minerals as well as in vitro antioxidant activities of Chromolaena odorata leaves. Methods: Phytochemical screening was carried out using standard procedure; mineral analysis was carried out using Atomic Absorption spectrophotometer while reducing power and DPPH radical scavenging activity were determined spectrophotometrically. Results: Phytochemical screening showed the presence of flavonoids, saponins, alkaloids, tannins etc. Mineral analysis showed the richness of Chromolaena odorata leaves in calcium (487.40mg/100g), sodium (44.22mg/100g), potassium (96.91mg/100g), magnesium (116.70mg/100g), zinc $(3.77 \mathrm{mg} / 100 \mathrm{~g})$, iron $(67.71 \mathrm{mg} / 100 \mathrm{~g})$, phosphate $(143.15 \mathrm{mg} / 100 \mathrm{~g})$ etc. The results on reducing power and DPPH radical scavenging activity indicates that at higher concentration, the plants ability to scavenge DPPH radical and reducing power ability increases. Conclusion: Chromolaena odorata leaves have potential for development of therapeutically active compounds which could serve as precursors for the design of potent and safe drugs.
\end{abstract}

Keywords: Chromolaena odorata, DPPH, Minerals, Phytochemicals, Reducing power

\section{INTRODUCTION}

Chromolaena odorata (L) King and Robinson belongs to the family Asteraceae and is known locally in Nigeria through many common names as Awolowo, siam weed, Elizabeth weed, obirakara, olorohuru and independence weed [1]. The plant was popularized by its effective wound healing property. The anti-microbial properties have made it a popular choice in disinfecting and treating open wounds [2]. The wider use as an effective therapy against diarrhoea, malaria fever, tooth ache, diabetes, skin diseases, dysentery and colitis has been severally documented [2-3]. The leaves could be ground and the extracted juice taken to alleviate fever or the treatment of diabetes [4]. This study is aimed at providing preliminary studies on Chromolaena odorata leaves

\section{Materials AND Methods}

\section{Collection, Identification and Preparation of Plant materials}

The fresh leaves of Chromolaena odorata were collected from a local farm in south eastern part of Nigeria. Identification and authentication were carried out after which the leaves were washed and air dried at room temperature for fourteen (14) days. They were grounded into fine powder using an electric blender and stored in a cool dry container until use for analysis.

\section{Phytochemical analysis}

Qualitative phytochemical screening using standard methods as described [5-9] were carried out.

\section{Mineral analysis}

Mineral analysis was carried out using Atomic Absorption Spectrophotometer (AAS) as previously done by Usunobun and Okolie, [10-11]. 


\section{Determination of reducing power ability}

The reducing power activity of Chromolaena odorata leaves was carried out using the reducing power method as described by Aiyegoro and Okoh [12]. A mixture containing $2.5 \mathrm{ml}$ of $0.2 \mathrm{M}$ phosphate buffer $(\mathrm{pH} 6.6)$ and $2.5 \mathrm{ml}$ of $\mathrm{K}_{3} \mathrm{Fe}(\mathrm{CN})_{6}(1 \% \mathrm{w} / \mathrm{v})$ was added to $1.0 \mathrm{ml}$ of stock Chromolaena odorata leaves filtrate $(0.2-1.0 \mathrm{mg} / \mathrm{ml})$ prepared in distilled water. The resulting mixture was incubated for $20 \mathrm{~min}$ at $50^{\circ} \mathrm{C}$, followed by the addition of $2.5 \mathrm{ml}$ of TCA $(10 \% \mathrm{w} / \mathrm{v})$, followed by centrifugation at $3000 \mathrm{rpm}$ for $10 \mathrm{~min}$. $2.5 \mathrm{ml}$ of the supernatant was mixed with $2.5 \mathrm{ml}$ of distilled water and $0.5 \mathrm{ml}$ of $\mathrm{FeCl}_{3}(0.1 \% \mathrm{w} / \mathrm{v})$. The absorbance was measured at $700 \mathrm{~nm}$ against reagent blank sample. Increased absorbance of the reaction mixture indicates higher reducing power of Chromolaena odorata leaves.

\section{2,2-diphenyl-1-picrylhydrazyl (DPPH) radical scavenging ability}

The DPPH method according to Liyana-Pathiana and Shahidi [13] was used for the determination of DPPH free radical scavenging activity of the Chromolaena odorata leaves as follows: DPPH (1 ml, $0.135 \mathrm{mM}$ ) prepared in methanol was mixed with $1.0 \mathrm{ml}$ of stock Chromolaena odorata leaves filtrate ranging in concentration from 0.2 to $1.0 \mathrm{mg} / \mathrm{ml}$. The reaction mixture was then vortexed thoroughly and left in the dark at room temperature for $30 \mathrm{~min}$. The absorbance was measured at $517 \mathrm{~nm}$. The scavenging ability was calculated using the equation: DPPH scavenging activity $(\%)=\left[\left(\mathrm{Abs}_{\text {control }}-\right.\right.$ $\left.\left.\left.\mathrm{Abs}_{\text {sample }}\right)\right] /\left(\mathrm{Abs}_{\text {control }}\right)\right] \times 100$,

Where: $\mathrm{Abs}_{\text {control }}$ is the absorbance of DPPH + methanol and $\mathrm{Abs}_{\text {sample }}$ is the absorbance of DPPH radical + sample (sample or standard).

\section{Statistical analysis}

Data obtained from this study were expressed as mean value \pm standard deviation.

\section{RESUlts AND CONCluSiON}

The preliminary phytochemical screening of Chromolaena odorata leaves showed the presence of various secondary metabolites including alkaloids, tannins, flavonoids, saponins etc as shown in Table 1. Phytochemical analysis of Chromolaena odorata leaves showed that it contains alkaloids, flavoloids, saponins, tannins, and steroids. The presence of secondary metabolites such as alkaloids, saponins, tannins, flavonoid will contribute to its medicinal value. The presence of saponins in this study justifies the cholesterol lowering properties of Chromolaena odorata as reported in a study by Nwankpa et al [14]. Saponins inhibit $\mathrm{Na}^{+}$efflux leading to higher $\mathrm{Na}^{+}$concentration in cells, thereby activating a $\mathrm{Na}^{+}-\mathrm{Ca}^{2+}$ antiport [15]. This effect produces elevated cytosolic $\mathrm{Ca}^{2+}$ which strengthens the contraction of the heart muscle and thereby reducing congestive heart failure [15]. The presence of tannins in this study give credence to the antimicrobial effects of Chromolaena odorata on some known human pathogens such as Staphyloccocus aureus, Escherichia coli and Candida albicans as reported by Mbajiuka et al [16]. The presence of flavonoids in this study give support to analgesic, anti-inflammatory and antipyretic activities reported by Owoyele et al [17].

Table 1. Phytochemicals present in Chromolaena odorata leaves

\begin{tabular}{|l|l|}
\hline Phytochemicals & $\begin{array}{l}\text { Chromolaena odorata } \\
\text { leaves }\end{array}$ \\
\hline Flavonoids & $+\mathrm{ve}$ \\
\hline Alkaloids & $+\mathrm{ve}$ \\
\hline Saponins & $+\mathrm{ve}$ \\
\hline Tannins & $+\mathrm{ve}$ \\
\hline $\begin{array}{l}\text { Cardiac } \\
\text { glycosides }\end{array}$ & $-\mathrm{ve}$ \\
\hline Anthraquinones & $-\mathrm{ve}$ \\
\hline Steroids & $+\mathrm{ve}$ \\
\hline
\end{tabular}

Where, + ve $=$ present, $-\mathrm{ve}=\mathrm{absent}$ 
Mineral analysis of Chromolaena odorata leaves as shown in table 2 shows the plant to be higher in calcium $(487.40 \mathrm{mg} / 100 \mathrm{~g})$ and least in manganese $(0.81 \mathrm{mg} / 100 \mathrm{~g})$. Minerals plays important roles in nutrition, metabolic pathways, acid-base balance, osmolarity, body homeostasis, improved intellectual performance, improved work capacity increased resistance to infection, etc. Calcium content of Chromolaena odorata $(487.40 \mathrm{mg} / 100 \mathrm{~g})$ is high when compared to $295 \mathrm{mg} / 100 \mathrm{~g}$ of Celosia argentea [18] but low when compared to $1118.30 \mathrm{mg} / 100 \mathrm{~g}$ of Annona muricata and $1264.18 \mathrm{mg} / 100 \mathrm{~g}$ of Vernonia amygdalina [10-11]. Potassium content of Chromolaena odorata $(96.91 \mathrm{mg} / 100 \mathrm{~g})$ is low when compared to $128.33 \mathrm{mg} / 100 \mathrm{~g}$ of Celosia argentea [18] but high when compared to $36.31 \mathrm{mg} / 100 \mathrm{~g}$ of Annona muricata and $62.79 \mathrm{mg} / 100 \mathrm{~g}$ of Vernonia amygdalina [10-11]. Sodium content of Chromolaena odorata $(44.22 \mathrm{mg} / 100 \mathrm{mg})$ compared favorably with $48.31 \mathrm{mg} / 100 \mathrm{~g}$ of Vernonia amygdalina [11] but is low compared to $69.49 \mathrm{mg} / 100 \mathrm{~g}$ of Annona muricata [10] and $71.32 \mathrm{mg} / 100 \mathrm{~g}$ of Celosia argentea [18]. Zinc content of Chromolaena odorata $(3.77 \mathrm{mg} / 100 \mathrm{~g})$ compared favorably with $5.42 \mathrm{mg} / 100 \mathrm{~g}$ of Celosia argentea [18] but is high compared to $0.83 \mathrm{mg} / 100 \mathrm{~g}$ of Annona muricata and $1.42 \mathrm{mg} / 100 \mathrm{~g}$ of Vernonia amygdalina [10-11]. Copper content of Chromolaena odorata $(1.41 \mathrm{mg} / 100 \mathrm{mg})$ compared favorably with $2.18 \mathrm{mg} / 100 \mathrm{~g}$ of Celosia argentea [18], $1.95 \mathrm{mg} / 100 \mathrm{~g}$ of Vernonia amygdalina and $1.42 \mathrm{mg} / 100 \mathrm{~g}$ of Annona muricata [10-11]. Magnesium content of Chromolaena odorata $(116.70 \mathrm{mg} / 100 \mathrm{~g})$ compared favorably with $122.50 \mathrm{mg} / 100 \mathrm{~g}$ of Celosia argentea [18] but low when compared to $961.9 \mathrm{mg} / 100 \mathrm{~g}$ of Annona muricata and $681.36 \mathrm{mg} / 100 \mathrm{~g}$ of Vernonia amygdalina [10-11].

Table 2. Minerals present in Chromolaena odorata leaves

\begin{tabular}{|l|l|}
\hline Minerals & $\begin{array}{l}\text { Chromolaena odorata } \\
(\mathrm{mg} / 100 \mathrm{~g})\end{array}$ \\
\hline Calcium & $487.40 \pm 1.06$ \\
\hline Magnesium & $116.70 \pm 1.01$ \\
\hline Potassium & $96.91 \pm 1.05$ \\
\hline Sodium & $44.22 \pm 1.02$ \\
\hline Phosphate & $143.15 \pm 1.04$ \\
\hline Iron & $67.71 \pm 1.01$ \\
\hline Zinc & $3.77 \pm 0.19$ \\
\hline Copper & $1.41 \pm 0.98$ \\
\hline Manganese & $0.81 \pm 0.10$ \\
\hline Chromium & $0.97 \pm 0.08$ \\
\hline
\end{tabular}

Values are means \pm SD for 2 determinations

The result of reducing power ability as shown in Figure 1 shows that Chromolaena odorata leaves has a dose-dependent effect as the reducing power ability of the plant increased with increasing concentrations from 0.2 to $1.0 \mathrm{mg} / \mathrm{ml}$. The ability of Chromolaena odorata leaves to scavenge DPPH chemical, a stable free radical with characteristic absorption at $517 \mathrm{~nm}$, and stable at room temperature is shown on Figure 2. The result indicates that at higher concentration, from 0.2 $1.0 \mathrm{mg} / \mathrm{ml}$, the plants ability to scavenge DPPH radical increases as shown by increased percentage (\%) inhibition. The use of DPPH scavenging assays in assessing the cell membrane integrity/cell membrane stabilizing capacities of plant constituents has given explanations as to the possible ways by which phytomedicine could help to reduce diseases caused by infections, inflammation and oxygen radical generation affecting the cell membrane [19]. Radical scavengers may directly react and quench peroxide radicals to terminate the peroxidation chain reaction and improve the quality and stability of food product. In this study, a higher percentage of the Chromolaena odorata leaves exhibited the ability to scavenge DPPH radical used in a concentration dependent manner as its \% Inhibition decreased with decrease in concentration. Photometric determination of antioxidant activity of Chromolaena odorata leaves showed that the plant possess a strong activity as a radical scavenger using DPPH assay indicating that Chromolaena odorata has very strong ability to donate hydrogen when compared with standard, Vitamnin C. 


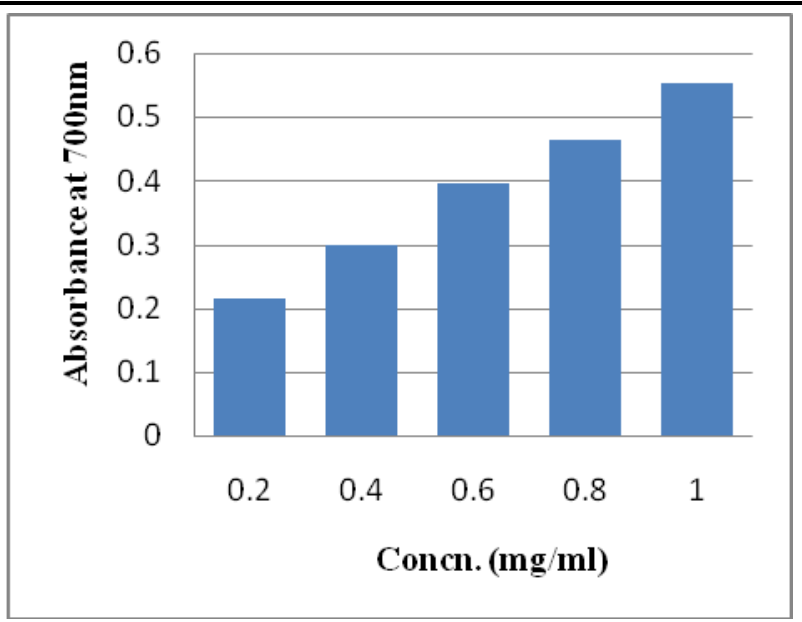

Figure 1. Reducing power ability of Chromolaena odorata leaves

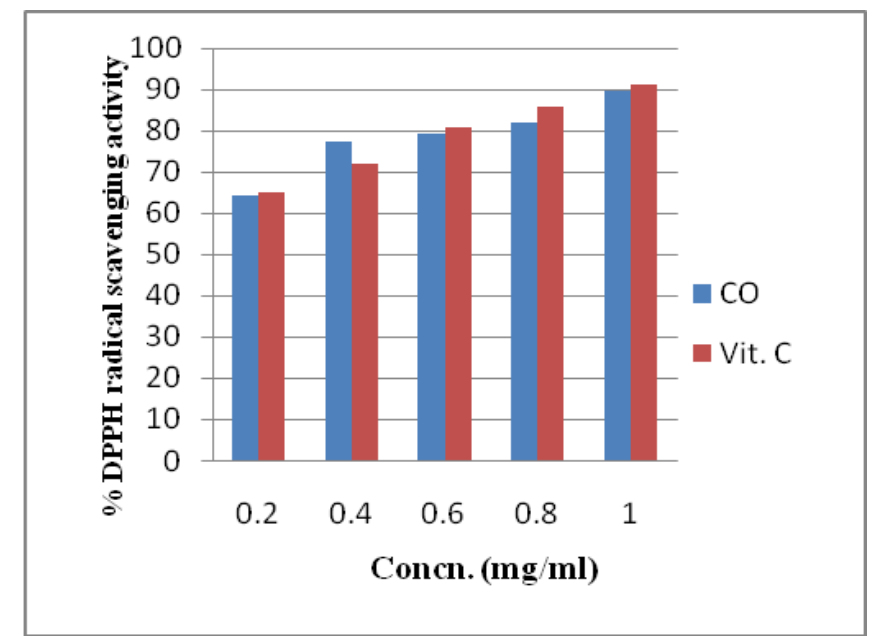

Figure 2. DPPH radical scavenging activity of Chromolaena odorata (CO) leaves

\section{Conclusion}

In conclusion, this study provides a scientific basis for further testing and characterization of the medicinal properties of individual compounds from Chromolaena odorata leaves.

Conflicts of interest: The authors declare that they have no conflict of interest.

\section{REFERENCES}

[1] Ngozi N., and Theresa O. Personal communication on the relevance and indigenous use of medicinal plants. 2014

[2] Odugbemi T. Outlines and pictures of medicinal plants from Nigeria. University of Lagos Press, Lagos, Nigeria, 2006; Pp. 1-283.

[3] Akinmoladun A. C., and Akinloye O. Effect of Cromolaena odorata on hypercholesterolemia related metabolic imbalances. Proc. Akure- Humbold Kellog/3rd SAAT Annual Conference, FUTA, Nigeria, 2007; pp 287-290.

[4] Chung I. M., and Yun S. J. Assessment of Allelopathic Potential of barnyard grass. Crop protection. 20, 921-928 (2001).

[5] Sofowora L. A. Medicinal plants and Traditional Medicine in Africa. Spectrum Books Ltd, Ibadan, 1993; pp55-71.

[6] Trease G. E. and Evans W. C. Pharmacognosy 11th Ed., Tindall Ltd, London, 1985; pp60-75.

[7] Harbone J. B. Methods of extraction and isolation. In: Phy-tochemical Methods. Chapman and Hall, London; 1998; Pp60-66.

[8] Usunobun U., Okolie N. P., Anyanwu O. G., Adegbegi A. J., and Egharevba M. E. Phytochemical screening and proximate composition of Annona muricata leaves. Eur. J. Bot, Plant Sci. Phytol. 2(1), 18-28 (2015). 
[9] Usunobun U. and Okolie P. N. Phytochemical analysis and proximate composition of Vernonia amygdalina. Int. J. Scienti. World 4(1), 11-14 (2016).

[10] Usunobun U. and Okolie N. P. Phytochemical analysis and mineral composition of Annona muricata leaves. Int. J. Res. Curr. Dev. 1(1), 38-42 9 (2015).

[11] Usunobun U. and Okolie N. P. Phytochemical, trace and mineral composition of Vernonia amygdalina leaves. Int. J. Biol. Pharma. Res. 6(5), 393-399 (2015).

[12] Aiyegoro O. A. and Okoh A. I. Preliminary phytochemical screening and in vitro antioxidant activities of the aqueous extract of Helichrysum longifolium DC. BMC Compl. Alter. Med. 10: 21-32 (2010).

[13] Liyana-Pathiana C. M., and Shahidi F. Antioxidant activity of commercial soft and hard wheat (Triticum aestivium $\mathrm{L}$ ) as affected by gastric $\mathrm{pH}$ conditions. J. Agric. Food Chem. 53: 2433-40 (2005).

[14] Nwankpa P., Eteng M. U., Oze G., Nwanjo H. U., and Ezekwe S. Effect of Chromolaena odorata on serum lipid profile and oxidative stress status in Salmonellae typhi infested wistar rats. Annals Biol. Res. 3(10), 4696-4700 (2012).

[15] Schneider G. and Wolfing J. Synthetic cardenolides and related compounds. Curr. Organic Chem. 8, 14 (2004).

[16] Mbajiuka C. S., Obeagu E. I., Chude C. N., and Ihezie OE. Antimirobial effects of Chromolaena odorata on some human pathogens. Int. J. Curr. Microbio. Appl. Sci. 3(3), 1006-1012 (2004)

[17] Owoyele B. V., Oguntoye S. O., Dare K., Ogunbiyi B. A., Aruboula E. A. and Soladoye A. O. Analgesic, anti-inflammatory and antipyretic activities from flavonoid fractions of Chromolaena odorata. J. Med. Plants Res. 2(9), 219-225 (2008).

[18] Usunobun U. and Ekpemupolo I. S. Phytochemical analysis, mineral composition and in vitro antioxidant activities of Celosia argentea leaves. Int. J. Sci. World 4(1), 19-22 (2016).

[19] Shahidi F. and Wanasundara P. K. Phenolic antioxidants. Crit. Rev. Food Sci. Nutri. 32(1), 67103 (1992) 